Lingua Rima: Jurnal Pendidikan Bahasa dan Sastra Indonesia

Vol. 10 No. 1 Januari 2021

http://jurnal.umt.ac.id/index.php/lgrm

\title{
ANALISIS KESALAHAN BERBAHASA DALAM TATARAN FONOLOGI PADA KANAL YOUTUBE "MAS BAS-BULE PRANCIS"
}

\author{
Nurul Raihan Lathifah ${ }^{1}$, \\ Universitas Ahmad Dahlan \\ Nurul1700003068@webmail.uad.ac.id \\ Febiana Dwi Anggita², \\ Universitas Ahmad Dahlan \\ Febianaanggita16@gmail.com \\ Selvi Rosianingsih ${ }^{3}$ \\ Universitas Ahmad Dahlan \\ Selvi1700003065@webmail.uad.ac.id
}

\begin{abstract}
ABSTRAK
Penelitian ini bertujuan untuk menganalisis kesalahan-kesalahan dalam penggunaan bahasa Indonesia pada tataran fonologi yang terdapat dalam kanal youtube "Mas Bas-Bule Prancis". Penelitian ini merupakan penelitian kulitatif dengan metode analisis data ialah metode padan fonetik artikulatoris dengan teknik dasar teknik pilah unsur penentu (PUP) dan teknik lanjutan teknik hubung banding menyamakan hal pokok (HBSP). Data dalam penelitian ini berupa video yang terdapat dalam kanal Youtube "Mas Bas- Bule Prancis" yang merupakan kesalahan berbahasa. Sumber datanya terdapat pada kanal Youtube yang bernama "Mas Bas- Bule Prancis." Teknik pengumpulan data dalam penelitian menggunakan ini metode simak. Teknik analisis data menggunakan reduksi data, penyajian data dan penarikan simpulan. Hasil penelitian ini menunjukkan kesalahan fonologi yang dilakukan oleh Mas Bas-Bule Prancis dalam kanal Youtube sebanyak 16 kesalahan. Kesalahan-kesalahan tersebut berupa kesalahan pengurangan fonem sebanyak 1 buah kesalahan, kesalahan penambahan fonem sebanyak 4 buah kesalahan, dan kesalahan penggantian fonem sebanyak 11 buah kesalahan. Kesalahan fonologi yang dilakukan oleh Mas Bas-Bule Prancis sangat lumrah dilakukan oleh penutur pemula atau penutur asing. Oleh karena itu, hasil dari penelitian ini dapat digunakan sebagai salah satu contoh kasus kesalahan bidang fonologi dan juga kasus pembelajaran BIPA.
\end{abstract}

Kata kunci : analisis kesalahan, tataran fonologi, Youtube

\section{A. PENDAHULUAN}

Bahasa merupakan identitas suatu bangsa yang muncul karena adanya kehidupan di masyarakat secara alami. Bahasa adalah pemersatu antara yang satu dengan lainnya dari skala keluarga, masyarakat hingga Negara. Mempelajari bahasa adalah hak siapa saja, sebab bahasa adalah budaya bangsa. Dengan belajar bahasa kita turut menjaga jati diri bangsa. Bahasa Indonesia disebut juga bahasa nasional, yang sangat mudah dipelajari. Banyak warga negara asing yang berminat untuk mempelajari bahasa Indonesia, baik untuk keperluan pekerjaan atau pun kepentingan hidup yang lainnya.

Banyak warga negara asing yang tertarik pada bahasa Indonesia, dan ingin untuk belajar Bahasa Indonesia. Namun, dalam proses belajar bahsa Indonesia, banyak pula warga 


\section{Lingua Rima: Jurnal Pendidikan Bahasa dan Sastra Indonesia \\ Vol. 10 No. 1 Januari 2021 \\ http://jurnal.umt.ac.id/index.php//grm}

negara asing yang salah dalam pengucapan kata-kata dalam bahasa Indonesia. Kesalahan berbahasa yang biasanya terjadi di kalangan penutur asing pemula ialah pada tataran fonologinya, kesalahan ini berkaitan dengan pengucapan fonem, penghilangan fonem, penambahan fonem, salah meletakkan penjedaan dan lainnya. Kesalahan berbahasa Indonesia dalam bidang fonologi dapat dilihat dari penggunaan bahasa baik secara lisan maupun tertulis. Namun sebagian besar kesalahan berbahasa Indonesia di bidang fonologi berkaitan dengan pengucapan, baik itu dalam pengucapan fonem, penghilangan fonem, penambahan fonem, salah meletakan penjedaan dan lainnya.

YouTube merupakan media sosial yang digunakan untuk membagikan informasi berupa video dan dapat ditonton oleh orang-orang seluruh dunia.Selain itu dapat juga dijadikan sebagai objek kajian dalam suatu penelitian, karena banyak sekali kanal youtube terutama pada kanal orang asing yang sering menggunakan Bahasa Indonesia. Sering terjadi kesalahan dan kekeliruan dalam proses pengucapan yang tidak sesuai dengan kaidah kebahasaan yang benar. Hal ini salah satu data yang diambil adalah dari kanal youtube milik penutur Prancis yang belajar bahasa Indonesia. Kanal youtube tersebut bernama "Mas Bas- Bule Prancis", dan dalam kanal youtube mas Bas membagikan berbagi aktivitasnya kepada khalayak dengan menggunakan bahasa Indonesia.

Bahasa berperan penting dalam kehidupan manusia. Melalui bahasa proses komunikasi antar manusia dapat berjalan dengan baik, sehingga pesan atau informasi yang ingin disampaikan pun dapat diterima dengan tepat. Hal tersebut dapat dibuktikan dengan terbentuknya kepelbagaian bahasa di dunia yang masing-masing memiliki ciri-ciri yang unik yang menimbulkan adanya perbedaan dengan bahasa lainnya (Septia, 2017).

Menurut Chaer dan Agustina (2004: 14) bahasa memiliki fungsi sebagai alat untuk berinteraksi atau alat untuk berkomunikasi, dalam arti lain sebagai alat untuk menyampaikan pikiran, ide atau gagasan, konsep, dan juga perasaan. Adanya interaksi antar penutur tersebut menunjukkan bahwa dengan menggunakan bahasa tertentu, pembicara akan dikenali siapa dirinya, dari mana ia berasa, juga bagaimana hubungannya dengan mitra tuturnya, dalam peristiwa tutur apa dan bagaimana dia terlibat dalam sebuah komunikasi (Saddhono, 2006).

Menurut Tarigan (1997:47) bahwa kesalahan berbahasa berhubungan erat dengan pengajaran bahasa, baik pengajaran bahasa pertama (B1) maupun kedua (B2). Di mana ada pengajaran bahasa dapat dipastikan di situ terjadi kesalahan berbahasa. Hal yang sama terjadi pula dalam pengajaran bahasa Indonesia, baik sebagai pengajaran bahasa pertama (B1) 


\section{Lingua Rima: Jurnal Pendidikan Bahasa dan Sastra Indonesia \\ Vol. 10 No. 1 Januari 2021 \\ http://jurnal.umt.ac.id/index.php/lgrm}

maupun sebagai pengajaran bahasa kedua (B2). Para guru bahasa Indonesia tentu ingin mengetahui apa sumber dan penyebab kesalahan tersebut.

Fonologi merupakan sebuah disiplin ilmuyang meneliti bunyibahasa tertentu menurut fungsinya. Dari hal tersebutlah kesalahan berbahasa bisa terjadi, karena bunyi yang dituturkan oleh penutur terkadang berbeda dengan bunyi bahasa yang sebenarnya. Sehingga makna dari kata yang dituturkan menjadi berbeda, bahkan tidak berarti. Penutur asing yang masih belajar bahasa Indonesia biasanya logat dari bahasa asli dari negaranya masih tertanam dalam diri mereka, sehingga untuk menuturkan bahasa Indonesia masih sulit dan suka terjadi kesalahan. Penutur asing yang belajar bahasa Indonesia biasanya suka membagikan pengetahuannya berbahasanya kepada penutur asing yang lain. Hal tersebut seringkali dibagikan melalui media sosialnya untuk berbagi pengetahuan dan dapat berguna sebagai media dokumentasi yang sesekali dapat dilihat kembali.

\section{B. METODOLOGI PENELITIAN}

Penelitian ini merupakan penelitian kulitatif dengan metode analisis data ialah metode padan fonetik artikulatoris dengan teknik dasar teknik pilah unsur penentu (PUP) dan teknik lanjutan teknik hubung banding menyamakan hal pokok (HBSP). Data dalam penelitian ini berupa video yang terdapat dalam kanal Youtube "Mas Bas- Bule Prancis" yang merupakan kesalahan berbahasa. Sumber datanya terdapat pada kanal Youtube yang bernama "Mas BasBule Prancis." Teknik pengumpulan data dalam penelitian menggunakan ini metode simak. Cara yang digunakan untuk memeroleh data dilakukan dengan menyimak penggunaan bahasa dalam tayangan tersebut dengan teknik dasar teknik sadap yaitu dengan mendengarkan penggunaan bahasa yang terdapat pada kanal Youtube yang bernama "Mas Bas- Bule Prancis". Teknik lanjutan teknik simak bebas libat cakap (SBLC) dan teknik catat (Sudaryanto, 2013:129). Teknik analisis data menggunakan reduksi data, penyajian data dan penarikan simpulan.

\section{PEMBAHASAN}

Penggunaan bahasa Indonesia pada kanal Youtube "Mas Bas-Bule Prancis" konten yang dibicarakan terdapat sangkut pautnya tentang bahasa Indonesia, sehingga mas Bas harus berbicara menggunakan bahasa Indonesia sepanjang durasi video Youtube nya. Hal tersebut berfungsi untuk melatih dirinya sendiri dalam menggunakan bahasa Indonesia dan memberikan informasi kepada orang lain tentang bahasa Indonesia. Sebagai penutur pemula, tak jarang mas Bas melakukan kesalahan saat berbicara bahasa Indonesia. Hasil penelitian 
Lingua Rima: Jurnal Pendidikan Bahasa dan Sastra Indonesia

Vol. 10 No. 1 Januari 2021

http://jurnal.umt.ac.id/index.php//grm

dan data pada kesalahan fonologi yang terdapat di kanal Youtube "Mas Bas- Bule Prancis" sebagai berikut.

\section{Pengurangan Fonem}

Terdapat pada video yang berjudul "MAS BAS DI MALANG ! (JAWA TIMUR)" menit ke (02:48) berupa kalimat "E Hani dan Ara aku sudah ketemu "degan" mereka di metting kecil aku organize kemarin". Pada video tersebut mas Bas menuturkan kata "degan” yang seharusnya ialah kata "dengan". Mas Bas mengurangkan fonem konsonan /n/ pada kata "dengan" sehingga disaat ia menuturkanya bunyi dari kata "dengan" menjadi berbeda makna. Makna yang ditimbulkan disaat menuturkan kata "degan" menjadi "kelapa".

\section{Penambahan Fonem}

Data 1

Terdapat pada video yang berjudul "4 KEMIRIPAN ANTARA INDONESIA DAN PERANCIS" menit ke (00:23-00:26) berupa kalimat "Aku mau "mengunnjungi” semua pulau di Indonesia”. Pada video tersebut mas Bas menuturkan kata "mengunnjungi" yang seharusnya ialah kata "mengunjungi". Mas Bas menambahkan fonem konsonan /n/ pada kata "mengunjungi" sehingga tuturan dari kata "mengunjungi" menjadi lebih tebal dan menekan pada saat dituturkan.

Data 2

Terdapat pada video yang berjudul "4 KEMIRIPAN ANTARA INDONESIA DAN PERANCIS" menit ke (02:50-02:55) berupa kalimat "Well teman-teman yang "terrpenting” adalah bahwa Indonesia". Mas Bas menuturkan kata "terrpenting” yang seharusnya ialah kata "terpenting”. Pada kata "terpenting” mas Bas menambahkan fonem konsonan /r/ pada kata "terpenting" sehingga tuturan dari kata "terpenting" menjadi lebih tegas pada saat dituturkan.

Data 3

Terdapat pada video yang berjudul "MAS BAS DI MALANG ! (JAWA TIMUR)" menit ke (02:22) berupa kalimat "aku tua "bangget", sudah tua ye, aku hamper E 30 tahun ye, aku tua bangget". Mas Bas menuturkan kata "bangget" yang seharusnya ialah kata "banget”. Pada kata "banget" mas Bas menambahkan fonem konsonan /g/, sehingga kata tersebut menjadi lebih tebal dan menekan pada saat dituturkan.

Data 4

Terdapat pada video yang berjudul "MAS BAS DI MALANG ! (JAWA TIMUR)" menit ke (03:36) berupa kalimat "Aku harap ini bisa buat mas Bas "semonggat" setiap hari 
Lingua Rima: Jurnal Pendidikan Bahasa dan Sastra Indonesia

Vol. 10 No. 1 Januari 2021

http://jurnal.umt.ac.id/index.php//grm

dan juga lebih keren". Mas Bas menuturkan kata "semonggat” yang seharusnya ialah kata "semangat". Pada kata "semangat" mas Bas menambahkan fonem konsonan /g/, sehingga kata "semangat" jika dituturkan akan lebih tebal dan menekan.

\section{Penggantian Fonem}

Data 1

Terdapat pada video yang berjudul "BAHASA INDONESIA SULIT, KAN ?” menit ke (00:38-00:47) berupa kalimat "Oke-oke bahasa Indonesia mudah sekali untuk "urangurang" Indonesia karena untuk ku ada beberapa kesulitan". Mas Bas menuturkan kata "urang-urang" yang seharusnya ialah kata "orang-orang”. Pada kata "orang-orang" mas Bas menggantikan fonem vokal /o/ menjadi fonem vokal /u/.

Data 2

Terdapat pada video yang berjudul "BAHASA INDONESIA SULIT, KAN ?

“ menit ke (01:44-01:54) berupa kalimat "Dan Ng Ng Ng sebelumnya aku gila dengan Ng itu "sekarong" lebih baik". Mas Bas menuturkan kata "sekarong” yang seharusnya ialah kata "sekarang". Pada kata "sekarang" mas Bas mengganti fonem vokal /a/ menjadi fonem vokal /o/, sehingga makna dari kata tersebut menjadi berbeda jika dituturkan. Makna yang ditimbulkan dari tuturan kata "sekarong" menjadi "karung".

Data 3

Terdapat pada video yang berjudul "BAHASA INDONESIA SULIT, KAN ? " menit ke (01:57-02:04) berupa kalimat "Kedua bahasa "gol” dalam semua bahasa-bahasa ada bahasa "gol" seperti bahasa Perancis". Mas Bas menuturkan kata "gol" yang seharusnya ialah kata "gaul". Pada kata "gaul" mas Bas menggantikan fonem vokal /a/dan/u/ menjadi fonem vokal /o/, sehingga makna dari kata menjadi berubah. Makna yang ditimbulkan dari kata "gol" dalam Kamus Besar Bahasa Indonesia ialah kata yang digunakan oleh penonton pertandingan bola, jika bola berhasil masuk kedalam gawang lawan.

Data 4

Terdapat pada video yang berjudul "BAHASA INDONESIA SULIT, KAN ? " menit ke (03:34-03:36) berupa kalimat "Tapi banyak kata-kata adalah "Sengat" berbeda". Mas Bas menuturkan kata "sengat" yang seharusnya ialah kata "sangat". Pada kata "sangat" mas bas menggantikan fonem vokal /a/ menjadi fonem vokal /e/, sehingga makna dari kata menjadi berubah. Makna yang ditimbulkan dari kata "sengat" dalam Kamus Besar Bahasa Indonesia ialah alat untuk menyerang/mempertahankan diri yang tajam dan berbisa pada serangga seperti lebah. 


\section{Lingua Rima: Jurnal Pendidikan Bahasa dan Sastra Indonesia \\ Vol. 10 No. 1 Januari 2021 \\ http://jurnal.umt.ac.id/index.php//grm}

\section{Data 5}

Terdapat pada video yang berjudul "4 KEMIRIPAN ANTARA INDONESIA DAN PERANCIS" menit ke (00:13-00:22) berupa kalimat "Pertama aku tahu di Indonesia ada banyak-banyak pulau hmm sekitar "tujuh beras ribu" kan". Mas Bas menuturkan kata "tujuh beras ribu" yang seharusnya ialah "tujuh belas ribu”. Pada kata "belas" mas Bas menggatikan fonem konsonan /l/ menjadi /r/, sehingga makna dari kata menjadi berubah. Makna yang ditimbulkan dari kata "beras" ialah padi yang terkelupas kulitnya yang akan menjadi nasi setelah ditanak.

Data 6

Terdapat pada video yang berjudul "MAS BAS DI MALANG ! (JAWA TIMUR)" menit ke (00:13) berupa kalimat "Sebelumnya aku sudah ke "Malong" bulan Mei, dan aku suka kota ini". Mas Bas menuturkan kata "Malong” yang seharusnya ialah kata "Malang”. Pada kata "Malong” mas Bas menggantikan fonem vokal /a/ menjadi fonem vokal /o/.

Data 7

Terdapat pada video yang berjudul "MAS BAS DI MALANG ! (JAWA TIMUR)" menit ke (00:37) berupa kalimat "Haloo teman-teman, aku kembali ke Indonesia, aku tinggal di Bali satu hari saja dan "longsong" ke "Molong". Mas Bas menuturkan kata "longsong" dan kata "Molong" yang seharusnya ialah kata "langsung" dan kata "Malang". Pada kata "longsong" mas Bas menggantikan fonem vokal /a/ dan /u/ menjadi fonem vokal /o/, dan pada kata "Malong" mas Bas menggantikan fonem vokal /a/ menjadi fonem vokal /o/.

Data 8

Terdapat pada video yang berjudul "MAS BAS DI MALANG ! (JAWA TIMUR)" menit ke (02:22) berupa kalimat "Oke makasih "mbah" makasih "deh" mungkin". Mas Bas menuturkan kata "mbah" dan "deh" yang seharusnya ialah "mbak" dan "dek". Pada kata "mbak" mas Bas menggantikan fonem konsonan $/ \mathrm{k} /$ menjadi fonem konsonan $/ \mathrm{h} /$, dan pada kata "deh" mas Bas menggantikan fonem konsonan /k/ menjadi /h/.

\section{Data 9}

Terdapat pada video yang berjudul "MAS BAS DI MALANG ! (JAWA TIMUR)" menit ke (02:48) berupa kalimat "Ini kado dari dua "orong". Mas Bas menuturkan kata "orong” yang seharusnya ialah kata"orang". Pada kata "orang” mas Bas menggantikan fonem vokal /a/ menjadi fonem vokal /o/.

Data 10 
Lingua Rima: Jurnal Pendidikan Bahasa dan Sastra Indonesia

Vol. 10 No. 1 Januari 2021

http://jurnal.umt.ac.id/index.php/lgrm

Terdapat pada video yang berjudul "MAS BAS DI MALANG ! (JAWA TIMUR)" menit ke (03:36) berupa kalimat "Aku harap ini bisa buat mas Bas "semonggat" setiap hari dan juga lebih keren”. Mas Bas menuturkan kata "semonggat" yang seharusnya ialah kata "semangat". Pada kata "semangat" mas Bas menggantikan fonem vokal /a/ menjadi fonem vokal /o/.

\section{Data 11}

Terdapat pada video yang berjudul "MAS BAS DI MALANG ! (JAWA TIMUR)" menit ke (04:47) berupa kalimat "Oo juga aku sudah ke Batu. Batu di gunung. Tapi aku lupa bikin video "tentong" ini". Mas bas menuturkan kata "tentong” yang seharusnya ialah kata “tentang”. Pada kata “tentang” mas Bas menggantikan fonem vokal /a/ menjadi fonem vokal /o/.

\section{E. SIMPULAN}

Hasil penelitian ini menunjukkan kesalahan fonologi yang dilakukan oleh Mas BasBule Prancis dalam kanal Youtube sebanyak16 kesalahan fonem. Kesalahan-kesalahan tersebut berupakesalahan pengurangan fonem sebanyak 1 buah kesalahan, kesalahan penambahan fonem sebanyak 4 buah kesalahan, dan kesalahan penggantian fonem sebanyak 11 buah kesalahan. Kesalahan fonologi yang dilakukan oleh Mas Bas-Bule Prancis termasuk kesalahan yang lumrah dilakukan oleh seseorang yang sedang belajar Bahasa Indonesia sehingga ia membuat video untuk mengasah bahasa Indonesia yang ia pelajari dengan membuat kontenpada kanal Youtube untuk memberikan informasi kepada orang lain dan juga untuk melatih dirinya sendiri dalam menggunakan bahasa Indonesia. Oleh karena itu, hasil dari penelitian ini dapat digunakan sebagai salah satu contoh kasus kesalahan bidang fonologi dan juga kasus pembelajaran BIPA

\section{F. DAFTAR PUSTAKA}

Bas. 2016. "BAHASA INDONESIA SULIT, KAN ?”. Mas Bas-Bule Prancis, 15 April 2016, dilihat 28 Maret 2020. https://www.youtube.com/watch?v=fqn1FNyFxoo.

Bas. 2016. "4 KEMIRIPAN ANTARA INDONESIA DAN PERANCIS”. Mas Bas-Bule Prancis, 8 April 2016, dilihat 28 Maret 2020. https://www.youtube.com/watch?v=pZi8KxNTlcs.

Bas. 2017. "MAS BAS DI MALANG ! (JAWA TIMUR)". Mas Bas-Bule Prancis, 20 November 2017, dilihat 28 Maret 2020. https://www.youtube.com/watch?v=Sd10JKBqaw. 
Lingua Rima: Jurnal Pendidikan Bahasa dan Sastra Indonesia

Vol. 10 No. 1 Januari 2021

http://jurnal.umt.ac.id/index.php//grm

Chaer, Abdul dan Leonie Agustina. 2004. Sosiolinguistik Perkenalan Awal.Jakarta: Rineka Cipta.

Djago Tarigan, 1997. Pendidikan dan Bahasa Sastra Indonesia di Kelas Rendah.

Jakarta: Universitas Terbuka.

Saddhono, K. 2006. "Bahasa Etnik Madura Di Lingkungan Sosial: KajianSosiolinguistik Di Kota Surakarta."Jurnal Publikasi Ilmiah, 8(34) : 1 - 15.

Septia, E. 2017. "Bahasa Pedagang Etnis Cina Dalam Interaksi Jual Beli DiPasar Pondok Kota Padang: Kajian Sosiolinguistik."Jurnal Gramatika, 3(1):1-8. doi: 10.22202/JG.2017.V3i1.1232.

Sudaryanto. 2013. Metode dan Aneka Teknik Analisis Bahasa: Pengantar Penelitian Wahana Kebudayaan Secara Linguistik. Yogyakarta: Duta Wacana University Pres. 